\title{
DAUR ULANG RECLAIMED ASPHALT PAVEMENT SEBAGAI BAHAN UTAMA CAMPURAN BETON ASPAL EMULSI UNTUK LAPIS PERMUKAAN
}

\author{
Anni Susilowati ${ }^{1}$, Andhika Kesuma ${ }^{2}$ \\ 1,2 Jurusan Teknik Sipil Politeknik Negeri Jakarta, Kampus Baru UI Depok 16424 \\ Email: ${ }^{1}$ anni_susilowati@yahoo.co.id, ${ }^{2}$ dhikaks@gmail.com
}

\begin{abstract}
Reclaimed Asphalt Pavement (RAP) material as a result of road maintenance by Scrapping-FillingOverlay method is a waste material which had potential to be recovered as a surface layerof road. The maintenance in highway road of Indonesia used hot mix asphalt in general. But, hot mix asphalt are not environmentally friendly and makes energy wasting because it needs burning process at mixing. Those things are the main causes of this research. This asphalt concrete with RAP with cold mixing is expected to fulfill the requirements of asphalt concrete for heavy traffic. In this research is asphalt content variations at 6,$5 ; 7,0 ; 7,5 ; 8,0 ;$ and $8,5 \%$ to total mixture. The results of this research shows that the highest Marshall stability could not reach minimum value of heavy loaded traffic, that is at emulsion asphalt content $7 \%$ only for $711 \mathrm{~kg}$. Besides, the percentage of void in mixture (VIM), void filled with bitumen (VFB) and flow couldn't fulfill the specification of SNI 8198:2015. With the result that optimum asphalt content cannot be obtained. Result of wheel tracking test could not be obtained too because the specimens collapse during the test.
\end{abstract}

Key words : Emulsion asphalt, Reclaimed Asphalt Pavement, stability, Wheel Tracking Machine

\begin{abstract}
ABSTRAK
Material Reclaimed Asphalt Pavement (RAP) hasil dari pemeliharaan dengan metode ScrappingFilling Overlay merupakan limbah yang berpotensi untuk dimanfaatkan kembali menjadi lapis permukaan. Pada umumnya penanganan jalan di Indonesia menggunakan campuran panas. Namun, campuran panas kurang ramah lingkungan dan tidak hemat energi. Karena membutuhkan proses pembakaran dalam proses pencampuran. Hal ini yang menjadi alasan utama penelitian ini. Beton aspal dengan bahan utama RAP dengan campuran dingin ini diharapkan mampu memenuhi syarat lapisan aspal beton untuk lalu lintas berat. Variasi pada penelitian ini adalah kadar aspal 6,5; 7,0; 7,5; 8,0; dan 8,5\% terhadap total campuran. Hasil dari penelitian menunjukan bahwa stabilitas Marshall tertinggi tidak mampu mencapai nilai minimum untuk lalu lintas berat, yaitu pada kadar aspal emulsi $7 \%$ hanya sebesar $711 \mathrm{~kg}$. Selain itu prosentase rongga dalam campuran (VIM), rongga terisi aspal (VFB) serta kelelehan tidak memenuhi spesifikasi dari SNI 8198:2015. Sehingga, kadar aspal optimum tidak didapatkan. Hasil dari pengujian alur roda juga tidak didapatkan karena benda uji amblas ketika pengujian dilakukan.
\end{abstract}

Kata kunci : Aspal emulsi, Reclaimed Asphalt Pavement, stabilitas, Wheel Tracking Machine

\section{PENDAHULUAN}

Sebagai negara berkembang, Indonesia membutuhkan jaringan jalan nasional yang memadai. Pada pengoperasiannya, jalan memerlukan pemeliharaan dengan rutin agar tetap dapat melayani pengguna jalan dengan baik. Salah satu pekerjaan pemeliharaan yang dilakukan adalah dengan metode ScrappingFilling Overlay (SFO).

SFO merupakan metode pemeliharaan untuk jalan perkerasan lentur. Metode ini mengupas lapis permukaan jalan aspal dan menggantinya dengan lapis aspal baru. Namun, proses ini 
menimbulkan material sisa hasil pengupasan yang cukup banyak. Material hasil pengupasan dari SFO disebut dengan Reclaimed Asphalt Pavement (RAP). Material RAP merupakan limbah yang berpotensi untuk dimanfaatkan kembali menjadi lapis ulang (overlay).

Pada umumnya penanganan jalan di Indonesia menggunakan campuran panas (hotmix), namun hotmix kurang ramah lingkungan dan tidak hemat energi karena membutuhkan proses pembakaran dalam proses pencampuran. Beton aspal campuran dingin (coldmix) lebih ramah lingkungan karena tidak memerlukan proses pembakaran sehingga tidak membutuhkan bahan bakar dan bebas polusi [1].

\section{Beton Aspal}

Beton aspal adalah jenis perkerasan jalan yang terdiri dari campuran agregat dan aspal, dengan atau tanpa bahan tambahan [2]. Suhu pencampuran ditentukan berdasarkan jenis aspal yang digunakan. Beton aspal campuran dingin (cold mix), dicampur pada suhu ruang sekitar $25^{\circ} \mathrm{C}$.

\section{Aspal Emulsi}

Aspal emulsi merupakan aspal yang dihasilkan dengan cara mendispersikan aspal keras ke dalam air atau sebaliknya dengan bantuan bahan pengemulsi.

Berdasarkan [1], untuk gradasi rapat (dense graded) dengan menggunakan bahan RAP maka digunakan aspal emulsi dengan tipe CSS (Cationic Slow Setting). Aspal Emulsi tipe CSS merupakan aspal emulsi yang lambat penguapan airnya. Aspal ini cocok digunakan untuk agregat yang mudah bereaksi pada area yang luas. Karena penyelimutannya akan lebih baik karena tidak langsung menguap.

\section{Reclaimed Asphalt Pavement (RAP)}

RAP adalah bahan yang berasal dari perkerasan beraspal lama yang biasanya diperoleh dengan cara menggaruk (milling) perkerasan beraspal lama [3]. Menurut [4], RAP merupakan material campuran agregat dan aspal yang dipakai ulang untuk pembuatan jalan. Daur ulang perkerasan aspal dinilai menguntungkan dari segi teknik, ekonomi dan lingkungan. Penggunaan RAP juga mengurangi limbah dari bongkaran jalan serta menjadi solusi pembuangan dari material pembongkaran jalan.

Penelitian [5], Nilai Marshalll Quotient hasil penelitian campuran recycling gradasi RAP hasil Ekstraksi pada kadar aspal optimum adalah 326,28 kg/mm dan campuran gradasi tanpa ekstraksi pada kadar aspal optimum adalah $259,57 \mathrm{~kg} / \mathrm{mm}$, jadi lebih besar dari 200 $\mathrm{kg} / \mathrm{mm}$. Bila dibandingkan dengan persyaratan campuran laston yaitu yaitu $200 \mathrm{~kg} / \mathrm{mm}$ sampai dengan $500 \mathrm{~kg} / \mathrm{mm}$ maka nilai Berdasarkan [6], Nilai stabilitas CAED tanpa semen sebesar 329 kg. Maka CAED ini cocok untuk perkerasan dengan lalu lintas ringan. CAED dengan penambahan $2 \%$ semen dengan stabilitas Marshall sebesar 873 kg dapat disetarakan dengan Campuran Lataston untuk Lapis Aus dengan nilai Stabilitas Marshall minimal $800 \mathrm{~kg}$ maupun Campuran Laston (AC) untuk Lapis Aus dan Lapis Antara dengan nilai stabilitas Marshall $800 \mathrm{~kg}$.

Berdasarkan penelitian [7], Aspal emulsi tipe CSS-1h dan aspal emulsi tipe CMS-1 dapat menggantikan aspal panas sebagai perkerasan jalan melihat stabilitasnya yang lebih tinggi dibanding aspal panas yaitu 1259 kg untuk tipe CSS-1h.

Tujuan dari penelitian ini adalah menentukan nilai karakteristik Marshall dari beton aspal campuran emulsi menggunakan RAP, menentukam nilai 
kekesatan dari beton aspal campuran menggunakan RAP, dan menentukan nilai ketahanan terhadap deformasi permanen dari beton aspal campuran emulsi menggunakan RAP setelah uji lintasan.

\section{METODE PENELITIAN}

Penelitian ini meliputi persiapan dan pengujian RAP, pengujian aspal emulsi, pembuatan benda uji, Pengujian stabilitas marshall/ Kemudian ditentukan kadar aspal emulsi optimum dan melakukan pengujian alur roda dan kekesatan pada kadar aspal emulsi optimum.

\section{Lokasi Penelitian}

Lokasi untuk pengujian kualitas aspal emulsi dilakukan di Laboratorium UPPP- PU DKI Jakarta. Lokasi penelitian untuk pembuatan benda uji hingga curing dan uji Marshall dilakukan di Laboraturium Politeknik Negeri Jakarta. Untuk uji lintasan (wheel tracking) dan uji kekesatan (skid resistance) dilakukan di Laboraturium Pusat Penelitian Jalan dan Jembatan Departemen Pekerjaan Umum Bandung.

\section{Bahan Penelitian}

Bahan-bahan yang akan digunakan dalam penelitian ini adalah Material RAP yang berasal dari proses Cold Milling dan Aspal Emulsi dengan tipe CSS-1h.

\section{HASIL dan PEMBAHASAN}

\section{Hasil Pengujian Bahan}

- RAP Halus

Hasil pengujian berat jenis, penyerapan air, nilai setara pasir serta kadar lumpur memenuhi spesifikasi [3] dapat dilihat pada Tabel 1.
- RAP Kasar

Hasil pengujian berat jenis, penyerapan air, serta kadar lumpur memenuhi spesifikasi [3] dapat dilihat pada Tabel 2.

- Aspal Emulsi

Hasil pengujian viskositas Saybolt Furol, stabilitas penyimpanan 24 jam, uji saringan, kadar aspal residu, penetrasi, daktilitas, kelarutan dalam trikloroetilena memenuhi spesifikasi [8] dapat dilihat pada Tabel 3.

\section{Variasi Kadar Aspal}

Perkiraan kadar aspal residu yang didapat dari perhitungan sebesar 7,63\% terhadap total campuran. Variasi yang digunakan adalah dua variasi di atas dan di bawah kadar aspal residu perkiraan. Sehingga variasi yang digunakan adalah 6,50\%; 7,00\%; 7,50\%; 8,00\%; dan $8,50 \%$.

\section{Hasil Pengujian Marshall}

Dari beberapa parameter dari Tabel 4, hanya VMA yang masuk ke dalam spesifikasi Laston dari [3]. Berdasarkan hasil yang didapat, terlihat bahwa VIM dan kelelehan terlalu besar. Sedangkan VFB dan stabilitas kurang dari syarat minimum. Hal ini disebabkan oleh tidak padatnya benda uji. Akibatnya stabilitas benda uji menurun karena campuran tidak kedap, sehingga mudah teroksidasi dan butiran mudah lepas karena lapisan aspal pada agregatnya tipis. Bila benda uji lebih padat, maka nilai VIM dan VMA akan menurun sehingga nilai VFB pun akan naik dan membuat benda uji memenuhi syarat. Namun nilai stabilitas memenuhi spesifikasi campuran aspal dingin berdasarkan Asphalt Institute MS-14 yaitu minimum $2224 \mathrm{~N}$ atau 222,4 kg. Sehingga dipilih kadar aspal 7\% dengan stabilitas tertinggi yaitu $711 \mathrm{~kg}$ untuk pengujian kekesatan dan alur roda. 


\section{Hasil Pengujian Kekesatan}

Hasil pengujian didapatkan nilai $\mathrm{Mu}-$ Meter sebesar 0,52. Nilai ini memenuhi Standar Pelayanan Jalan Tol menurut Peraturan Menteri Pekerjaan Umum No. 16/PRT/M/2014 yaitu minimal 0,33.

\section{Hasil Pengujian Alur Roda (Wheel Tracking)}

Pengujian Alur roda tidak dapat dianalisis karena tidak adanya data hasil pengujian. Hal ini disebabkan oleh amblasnya benda uji sedalam $5 \mathrm{~cm}$ sebelum terselesaikannya pengujian. Sehingga alat Wheel Tracking tidak mengeluarkan data deformasi benda uji.

\section{KESIMPULAN}

Berdasarkan hasil pengujian dapat ditarik kesimpulan bahwa:

1. Dari hasil pengujian marshall campuran beton aspal emulsi dengan spesifikasi Campuran Aspal Panas tidak memenuhi persyaratan untuk lalu lintas berat. Hal tersebut dikarenakan tidak didapatkan nilai kadar optimum karena tidak masuknya nilai Stabilitas, Kelelehan, VIM, dan VFB ke dalam spesifikasi SNI 8198:2015. Hanya VMA yang memenuhi syarat. Dilihat dari nilai stabilitas yang semakin turun dan kelelehan yang sangat besar diperkirakan beton aspal mengalami kelebihan aspal. Hal ini disebabkan tidak diperhitungkannya kadar aspal yang ada pada RAP karena diasumsikan tidak akan mengganggu karena pencampuran tidak menggunakan panas. Nilai Stabilitas tertinggi terdapat pada kadar aspal $7 \%$ yang hanya mencapai $711 \mathrm{~kg}$. Namun jika dengan Spesifikasi Campuran Aspal dingin, nilai stabilitasnya memenuhi karena syaratnya diatas $300 \mathrm{~kg}$.
2. Pengujian kekesatan menghasilkan nilai BPN yang dikonversikan ke nilai Mu-Meter. Nilai Mu-Meter yang didapat dari hasil pengujian memenuhi syarat minimal 0,33 $\mathrm{Mu}-$ Meter. Dengan demikian maka permukaan jalan memiliki gaya gesek yang baik antara permukaan jalan pada kondisi basah dengan ban kendaraan.

3. Pengujian alur roda sampel beton aspal RAP pada suhu $60^{\circ} \mathrm{C}$ tidak didapatkan data. Hal ini dikarenakan benda uji amblas sampai dasar (5 $\mathrm{cm})$ pada saat pengujian berlangsung. Sehingga, alat WTM tidak mengeluarkan data pengujian. Amblas nya benda uji terjadi akibat rendahnya stabilitas Marshall dan tingginya nilai kelelehan sehingga benda uji menjadi lunak dan tidak mampu menahan tekanan dari alat WTM.

\section{UCAPAN TERIMAKASIH}

Dalam kesempatan ini penulis banyak mengucapka terima kasih kepada pihak yang telah membantu penelitian ini terutama kepada kepala P3M Politeknik Negeri Jakarta yang telah menyalurkan dana, mas Kusno dan teman-teman Konsentrasi Jalan Tol yang telah membantu pada proses pelaksanaan di laboraturium.

\section{DAFTAR PUSTAKA}

[1] Transportation Research Board. 2006. Transportation Research Circular: Asphalt Emulsion Technology. Transportation Research Board. Washington DC.

[2] Sukirman, Silvia. 2003. Beton Aspal Campuran Panas. Edisi 1. Jakarta: Granit.

[3] SNI 8198:2015. 2015. Spesifikasi Campuran Beraspal Panas Bergradasi Menerus (Laston). Badan Standarisasi Nasional. 
[4] Al-Qadi, Imad L. 2007. Reclaimed Asphalt Pavement - A Literature Review, Illinois Center for Transportation, Illinois.

[5] Emrizal. 2009. Pemanfaatan Material Daur Ulang Aspal Beton Untuk Material Aspal Beton Campuran Dingin Memakai Aspal Emulsi. Universitas Sebelas Maret, Surakarta.

[6] Muliawan, I Wayan. 2011, Analisis Karakteristik dan Peningkatan Stabilitas Campuran Aspal Emulsi
Dingin (CAED). Denpasar: Universitas Udayana.

[7] Hartanto dkk. Analisa Karakteristik Campuran Aspal Emulsi Dingin dan Perbandingan Stabilitas Aspal Emulsi dengan Laston. Surabaya: Universitas Kristen Petra.

[8] SNI 4798:2011. 2015. Spesifikasi Aspal Emulsi Kationik. Badan Standarisasi Nasional.

Tabel 1. Rangkuman Pengujian RAP Halus

\begin{tabular}{lcc}
\hline \multicolumn{1}{c}{ Pengukuran } & Hasil & Spesifikasi SNI 8198:2015 \\
\hline RAP Halus & & - \\
Berat Jenis & 2,09 & - \\
Bj SSD & 2,10 & - \\
Bj Semu & 2,12 & $<3 \%$ \\
Penyerapan Air & $0,60 \%$ & $>50 \%$ \\
Nilai Setara Pasir & $90 \%$ & $<10 \%$ \\
Kadar Lumpur & $2,85 \%$ & \\
\hline
\end{tabular}

Tabel 2. Rangkuman Pengujian RAP Kasar

\begin{tabular}{lcc}
\hline \multicolumn{1}{r}{ Pengukuran } & Hasil & Spesifikasi SNI 8198:2015 \\
\hline RAP Kasar & & - \\
Berat Jenis & 2,29 & - \\
Bj SSD & 2,34 & - \\
Bj Semu & 2,40 & $<3 \%$ \\
Penyerapan Air & $2,01 \%$ & $<1 \%$ \\
Kadar Lumpur & $0,45 \%$ & \\
\hline
\end{tabular}

Tabel 3. Rangkuman Pengujian Aspal Emulsi

\begin{tabular}{lcc}
\hline \multicolumn{1}{c}{ Pengukuran } & Hasil & Spesifikasi SNI 4798:2011 \\
\hline Viskositas, Saybolt Furol $25^{\circ} \mathrm{C}$ & 33 detik & $20-100$ detik \\
Stabilitas Penyimpanan 24 Jam & $0,26 \%$ & $<1 \%$ \\
Uji Saringan & $0,03 \%$ & $<0,1 \%$ \\
Kadar Aspal Residu & $59,39 \%$ & $>57 \%$ \\
Penetrasi & 69,70 & $40-90$ \\
Daktilitas & $67 \mathrm{~cm}$ & $>40 \mathrm{~cm}$ \\
Kelarutan dalam Trikloroetilena & $98,34 \%$ & $>97,5 \%$ \\
Berat Jenis Aspal & 1,01 & - \\
\hline
\end{tabular}


Anni Susilowati dan Andhika Kesuma, Daur Ulang Reclaimed...

Tabel 4. Rangkuman Pengujian

\begin{tabular}{lrrrrrc}
\hline \multirow{2}{*}{ Parameter } & \multicolumn{5}{c}{ Kadar Aspal } & \multirow{2}{*}{ Syarat } \\
\cline { 2 - 6 } & $6,50 \%$ & $7,00 \%$ & $7,50 \%$ & $8,00 \%$ & $8,50 \%$ & \\
\hline \% Rongga dalam Agregat (VMA) & $23,95 \%$ & $23,87 \%$ & $25,77 \%$ & $24,47 \%$ & $25,60 \%$ & $>15 \%$ \\
\% Rongga dalam Campuran (VIM) & $12,43 \%$ & $11,38 \%$ & $12,66 \%$ & $10,16 \%$ & $10,54 \%$ & $3 \%-5 \%$ \\
\% Rongga terisi Aspal (VFB) & $48,16 \%$ & $52,33 \%$ & $50,89 \%$ & $58,49 \%$ & $58,91 \%$ & $>65 \%$ \\
Stabilitas & $685 \mathrm{~kg}$ & $711 \mathrm{~kg}$ & $502 \mathrm{~kg}$ & $613 \mathrm{~kg}$ & $393 \mathrm{~kg}$ & $>800 \mathrm{~kg}$ \\
Kelelehan & 14,35 & 14,33 & 15,4 & 12 & 13,85 & $2-4$ \\
\hline
\end{tabular}

